Wilfrid Laurier University

Scholars Commons @ Laurier

$9-2012$

\title{
Assessing Devolution in the Canadian North: A Case Study of the Yukon Territory
}

Christopher Alcantara

Wilfrid Laurier University, calcantara@wlu.ca

Kirk Cameron

Government of the Yukon

Steven Kennedy

Wilfrid Laurier University

Follow this and additional works at: https://scholars.wlu.ca/poli_faculty

Part of the Political Science Commons

\section{Recommended Citation}

Alcantara, Christopher; Cameron, Kirk; and Kennedy, Steven, "Assessing Devolution in the Canadian North: A Case Study of the Yukon Territory" (2012). Political Science Faculty Publications. 29.

https://scholars.wlu.ca/poli_faculty/29

This Article is brought to you for free and open access by the Political Science at Scholars Commons @ Laurier. It has been accepted for inclusion in Political Science Faculty Publications by an authorized administrator of Scholars Commons@ Laurier. For more information, please contact scholarscommons@wlu.ca. 


\title{
Assessing Devolution in the Canadian North: A Case Study of the Yukon Territory CHRISTOPHER ALCANTARA, ${ }^{1,2}$ KIRK CAMERON ${ }^{3}$ and STEVEN KENNEDY ${ }^{1}$
}

\author{
(Received 20 October 2011; accepted in revised form 14 February 2012)
}

\begin{abstract}
Despite a rich literature on the political and constitutional development of the Canadian territorial North, few scholars have examined the post-devolution environment in Yukon. This lacuna is surprising since devolution is frequently cited as being crucial to the well-being of Northerners, leading both the Government of Nunavut and the Government of the Northwest Territories to lobby the federal government to devolve lands and resources to them. This paper provides an updated historical account of devolution in Yukon and assesses its impact on the territory since 2003. Relying mainly on written sources and 16 interviews with Aboriginal, government, and industry officials in the territory, it highlights some broad effects of devolution and specifically analyzes the processes of obtaining permits for land use and mining. Our findings suggest that devolution has generally had a positive effect on the territory, and in particular has led to more efficient and responsive land use and mining permit processes.
\end{abstract}

Key words: devolution, Yukon Territory, land use, mining permits

RÉSUMÉ. Malgré le grand nombre de publications au sujet du développement politique et constitutionnel du Nord territorial canadien, peu d'érudits ont étudié la période ayant suivi le transfert des responsabilités au Yukon. Cette lacune surprend car le transfert des responsabilités est souvent cité comme étant crucial au bien-être des gens du Nord, ce qui a incité tant le gouvernement du Nunavut que celui des Territoires du Nord-Ouest à exercer des pressions sur le gouvernement fédéral en vue du transfert des terres et des ressources. Cet article présente l'historique actualisé du transfert des responsabilités au Yukon et évalue ses incidences sur le territoire depuis 2003. Il s'appuie principalement sur des sources écrites et sur 16 entrevues avec des Autochtones, des représentants des gouvernements et des représentants d'industries du territoire pour mettre en évidence certains effets à grande échelle du transfert des responsabilités et analyser plus précisément les processus d'obtention de permis en vue de l'utilisation des terres et de l'exploitation minière. Nos constatations suggèrent que le transfert des responsabilités a eu des effets favorables sur le territoire et qu'il a mené à des processus d'établissement de permis plus efficaces et plus responsables en matière d'utilisation des terres et d'exploitation minière.

Mots clés : transfert des responsabilités, territoire du Yukon, utilisation des terres, permis d'exploitation minière

Traduit pour la revue Arctic par Nicole Giguère.

\section{INTRODUCTION}

Over the last decade, the North has become a highly salient region for academics, policy makers, and the general public in Canada. Historians and policy makers have spent considerable time examining our country's claims to Arctic sovereignty in the region (Coates et al., 2008). Scientists have studied the Canadian Arctic to understand the consequences of climate change (e.g., Martin et al., 2007). Industry and government officials have put great effort into exploring and exploiting the many non-renewable resource deposits that were previously inaccessible because of harsh weather conditions and technological constraints (Hoefer, 2009:407-408). Scholars in the humanities and social sciences have also spent significant time in the area, examining the variety of indigenous land claims and innovative self-government initiatives that have emerged there
(Henderson, 2007; White, 2008; Alcantara and Whitfield, 2010). Finally, researchers have long been interested in the political and constitutional maturation of the Canadian North, with a particular focus on how devolution has transformed the territories into quasi-provinces with significant powers and resources (Cameron and Campbell, 2009; Dacks, 1990; McArthur, 2009; White, 2009; Alcantara, 2012).

Despite this rich and varied literature (see also Abele et al., 2009), scholars have yet to describe and analyze the impact of a number of important and recent developments relating to territorial devolution in the Canadian North. In particular, the Government of Yukon in 2003 achieved what no other territorial government has yet been able to achieve: jurisdiction over territorial lands and resources. Two landmark agreements in 1993 and 2001 facilitated this transfer. The first was the Umbrella Final Agreement (UFA)

\footnotetext{
${ }^{1}$ Department of Political Science, Wilfrid Laurier University, Waterloo, Ontario N2L 3C5, Canada

${ }^{2}$ Corresponding author: calcantara@wlu.ca

${ }^{3}$ Former Deputy Minister and Cabinet Secretary, Government of Yukon, 2C-508 Hanson St., Whitehorse, Yukon Y1A 1Z1, Canada

(C) The Arctic Institute of North America
} 
signed by the Government of Canada, the Council of Yukon Indians (now, the Council of Yukon First Nations), and the Yukon government on 29 May 1993. The UFA provides the framework within which each of the 14 Yukon First Nations could conclude final land-claim agreements. The UFA addresses a number of topics, including land ownership, compensation moneys, self-government, and the establishment of boards, committees, and tribunals to ensure the joint management of a number of specific areas. With regard to devolution of lands and resources specifically, the UFA is important because it establishes formal representation for Yukon First Nations on the Yukon Environmental and Socio-Economic Assessment Board (YESAB), one of the joint management bodies created by the UFA and a crucial component of the land use and mining permit processes in Yukon since devolution.

The second agreement is the Yukon Northern Affairs Program Devolution Transfer Agreement (DTA), which was signed by the Government of Canada and the Yukon government on 29 October 2001 and came into effect in 2003 (Yukon Government, 2001; CBC, 2003). With the signing of the DTA, the Yukon government became the only territorial government in the North to have administrative control over its lands and resources. As a result of this agreement, the federal government of Canada relinquished to the Yukon government legislative authority over territorial lands and associated surface and subsurface resources such as forestry and minerals. The transfer also included jurisdiction over Yukon waters, as well as ownership of many federal properties, assets, and contracts relating to what is now called the Department of Aboriginal Affairs and Northern Development's Northern Affairs Program (NAP) in the territory (Yukon Government, 2001).

Commentators at the time hailed the DTA as an important milestone for the constitutional and political development of Yukon. Former Yukon Premier Dennis Fentie, for instance, said in 2003 that the DTA "will lead to positive changes for Yukon people. In the short term, the Yukon will acquire direct control over resource management-and thus the ability to respond quickly and effectively to issues as they arise. In the long term, Yukon people will gain a comprehensive and consistent management regime for forests, lands, water and mining" (Fentie, 2003). To date, however, scholars have conducted very little empirical work on the effects of these developments. Thus, it is unclear what kind of impact these transfers of legislative administrative responsibility over Yukon lands and resources have had on advancing "good government" in the territory.

This paper aims to address this lacuna by examining two normative claims frequently associated with devolution in general and with devolution specifically in the Canadian North. First, defenders of devolution argue that transferring power from the federal to the territorial government tends to improve government efficiency. Second, devolution is said to improve government responsiveness. Using primary and secondary sources and 16 semi-structured interviews with Aboriginal, territorial, and industry representatives
(Table 1), we analyze these claims by focusing on the effect of the DTA and YESAB on the land use and mining permit processes in Yukon. Each representative was interviewed in person once for 30 to 90 minutes.

\section{THEORETICAL CONSIDERATIONS}

Devolution is commonly characterized as an empirical phenomenon involving the transfer of powers and responsibilities from the federal to the territorial governments (Clancy, 1990; Rodríguez-Pose and Gill, 2002; Whitford, 2002; Bradbury and Mitchell, 2005; Natcher and Davis, 2007). However, the concept is also frequently analyzed and justified from a normative perspective (Rondinelli, 1980; Escobar-Lemmon, 2003; Smoke, 2003). Much of this normative literature tends to defend devolution by focusing on two interrelated benefits. The first is that devolution fosters more efficient governance practices because sub-national authorities are better positioned to access and make use of local knowledge and context. As a result, territorial governments can more efficiently gather information, design policy, and implement it (Rondinelli, 1980; Bukowski, 1997; De Vries, 2000; Escobar-Lemmon, 2003). Efficiency gains are also realized because sub-national governments can carry out these functions more quickly than a higher level of government can. For instance, research suggests that federal involvement in on-reserve land management in Canada tends to be much less efficient in terms of transaction times because of the geographic distance between the decision makers and the local community (Alcantara, 2005).

In many ways, this efficiency argument, in which subnational governments are better at identifying and delivering "the mix and level of services that their constituents need" (Smoke, 2003:9), is similar to the principle of subsidiarity. This principle is best known for its articulation in Article $3 b$ of the Maastricht Treaty on European Union (1993), which states that "the European Community can only take action in a concurrent policy field if and in so far as the objectives of the proposed action cannot sufficiently be achieved by the member states and can therefore, by reason of the scale or effects of the proposed action, be better achieved by the Community" (Hueglin, 2007:202). According to Føllesdal (1998:190), the European principle of subsidiarity is a normative vision of multilevel governance in which "powers or tasks should rest with the lower-level sub-units ... unless allocating them to a higher-level central unit would ensure higher comparative efficiency or effectiveness in achieving them."

A second major benefit of devolution is that it encourages government responsiveness. When responsibility for territorial issues is located at the territorial rather than the federal level, local politicians and civil servants face stronger incentives and hold greater capacity to address the wide-ranging economic, and to some extent social, interests of their electorate. Territorial citizens are also more likely to monitor the actions of their political leaders and civil 
TABLE 1. List of interviewees, Whitehorse Yukon.

\begin{tabular}{lll}
\hline \hline Name & Title & Date of Interview \\
\hline S. Abercrombie & Executive Director, Energy, Mines and Resources & 19 November 2010 \\
J. Colbert & Official in the Yukon Government Lands Branch & 17 November 2010 \\
J. Cunning & Former Principal Secretary to Premier Duncan & 16 November 2010 \\
G. Komaromi & Assistant Deputy Minister, Energy, Mines and Resources & 19 November 2010 \\
D. Leas & Legal counsel for the Council of Yukon First Nations & 22 November 2010 \\
B. Love & Assistant Deputy Minister, Energy, Mines and Resources & 19 November 2010 \\
P. McDonald & Former Premier of the Yukon Territory & 15 November 2010 \\
B. McIntyre & Manager, Energy, Mines and Resources, Mineral Planning and Development Branch & 18 November 2010 \\
K. McKinnon & Board member, YESAB & 23 November 2010 \\
P. Muir & Justice official, Yukon Government & 19 November 2010 \\
J. O'Farrell & Deputy Minister, Community Services & 15 November 2010 \\
A. Robertson & Deputy Minister, Energy, Mines and Resources & 19 November 2010 \\
S. Smyth & Assistant Deputy Minister, Executive Council Office, Yukon Government & 17 November 2010 \\
B. Sproule & Official in the Yukon Government Lands Branch & 17 November 2010 \\
M. Wark & Executive Director, Yukon Chamber of Mines & 17 November 2010 \\
M. White & Official in the Yukon Government Lands Branch & 17 November 2010 \\
\hline \hline
\end{tabular}

${ }^{1}$ YESAB $=$ Yukon Environmental and Socio-Economic Assessment Board

servants (Hayek, 1945). In addition, devolution enhances responsiveness by ensuring that local issues no longer have to compete with the agendas of other sub-national and national units within the federation. Proponents of devolution suggest that making sub-national leaders responsible for sub-national decisions, removing local concerns from the national arena and placing them into the hands of territorial actors, will ensure that decision makers are more in tune with and responsive to local needs (De Vries, 2000; Escobar-Lemon, 2003).

In short, proponents suggest that devolution is advantageous because it improves government efficiency and responsiveness at the sub-national level. On the one hand, devolution encourages governance at the territorial level to be more efficient in terms of generating outcomes. On the other hand, devolution fosters increased government responsiveness, since territorial government actors are more likely to be sensitive to local concerns and contexts.

\section{YUKON DEVOLUTION: A HISTORY}

The evolution of public government in Yukon took a tortuous path between the territory's creation in 1898 and the implementation of the DTA in 2003. One of the most important advances occurred in 1908, the year a wholly elected territorial council, the term used then for a "legislative assembly," was established. Prior to that time, the council had comprised a mix of elected and federally appointed officials. Another major advance came a full 71 years later in 1979, with completion of the process for transferring all executive authorities of the Yukon government, in effect the Cabinet function, to individuals who had been elected to the territorial council. Through a letter of instruction from the Minister of Indian Affairs and Northern Development, Jake Epp, then-Commissioner Ione Christensen was ordered to relinquish her executive powers. Prior to the Epp Letter, the powers of the Commissioner of the territory were similar to those normally associated with provincial premiers, whereas now the Commissioner is equivalent to a provincial lieutenant governor (Cameron and Gomme, 1991). With the Commissioner no longer in charge of territorial affairs, party politics and the Westminster system commonly enjoyed by the provinces were ushered in. Since that time, successive governments have resembled their provincial counterparts, operating under the principles of representative and responsible government (Cameron and White, 1995; Alcantara, 2012).

The evolution of the structure of the Yukon government was accompanied by the evolution of the substance of its governance business. From the creation of the territorial government in 1898 through the 1950s, its jurisdiction largely covered social programming and subordinate government functions: what is normally referred to as municipal government. While the devolution of formerly federal responsibilities to the Yukon government is not a new phenomenon, the list of powers of the territorial government was quite minimal, and in no instance included jurisdiction on matters relating to ownership, administration, or control of land and resources. This pattern is consistent with the progress experienced in the early days of Saskatchewan and Alberta: provincial status did not change Crown ownership of land and resources. Transfer of power over land and resources to these provinces did not occur until 1930, a quarter-century after their creation in 1905 (Alcantara, 2012).

After the Second World War, a series of programs directly related to Yukon residents was gradually transferred to the Yukon territorial government: certain health services, police and corrections services, maintenance of the Alaska Highway, and the administration of justice (Michael, 1987; Clancy, 1990; Beaubier and Beaubier, 2002). These early transfers were necessitated by the growing population's demand for enhanced government services in the post-war years and "their variety underlined the increasingly complex character of the territorial government in the era of the welfare state" (Clancy, 1990:22). It is worth noting, however, that the federal government at this 
time did not have a coherent policy regarding the transfer of such programs. The result is that the nascent process of devolution proceeded on a case-by-case basis and far too slowly for the tastes of many in Yukon. Moreover, those transfers that were completed focused more on decentralizing organizational capacity than on enhancing legislative authority (Clancy, 1990).

With no law-making authority and only limited ability to determine the pace and scope of further program transfers, the Yukon territorial government had no control over the devolution agenda, which remained firmly in the hands of the federal government. For instance, as part of a transfer agreement signed in 1972, the federal Department of Fisheries agreed to devolve the administration and management of freshwater fisheries, the licensing of sport and commercial fishing, and the enforcement of fishing regulations to the territorial government. However, over a period of two years, the federal government unilaterally revised the terms of the initial agreement and eventually reneged on its commitments under the original proposal. Faced with the prospect of walking away empty-handed, the territorial government reluctantly accepted the federal government's modified proposal, which transferred only control over the sale and distribution of fishing licenses (Michael, 1987). It was evident that despite the growing political maturation of the territorial government in the post-war years, the continued lack of legislative and administrative authority would prove to be a significant roadblock in Yukon's political development over the latter half of the 20th century.

Even before the truncated fisheries transfer, the further devolution of programs to the Yukon government was unduly shaped by the prerogatives of the federal government. By the late 1960 s, with the angry reaction of Aboriginal groups to the federal government's 1969 White Paper and the push by the Department of Indian Affairs and Northern Development (DIAND) to control the northern resource boom that followed on the heels of the Prudhoe Bay oil strike in Alaska, the pace of transfers had virtually ground to a halt (Clancy, 1990). In the case of the White Paper, Canada's First Nations saw the federal government's proposal to dismantle the Indian Affairs Branch and transfer administration of status Indians to the provinces and territories as an "abrogation of its responsibilities that would amount to cultural genocide" (Michael, 1987:95). During the 1970s, only those programs that did not conflict with land claims and other federal priorities were transferred to the territorial government: road construction, airports, the Northern Canada Power Commission, fishing licenses, mine safety, and land titles (Beaubier and Beaubier, 2002). The long sought-after ownership and management of natural resources remained beyond the grasp of territorial leaders.

In the 1970s, the territorial debate and pressure on Ottawa to transfer land and resources coincided with the rise of land-claim negotiations with Yukon's Aboriginal peoples. Yukon politicians in the late 1970s and early 1980s argued successfully that it was unfair to give significant land ownership to the Aboriginal population without giving the capacity to the regional (territorial) government to manage land and resources throughout the territory. Many years of debate followed on what should be transferred and in what order (forestry, oil and gas, minerals, land...), what the territorial government could handle (capacity of the territorial government), and what jurisdictions the federal government should retain in the name of defending the national interest. The frequent turnover of federal ministers in DIAND also created setbacks for devolution since it took time to brief new ministers before further devolution could occur. New ministers often have different perspectives than their predecessors, and new governments usually revisit and change the programs and legislation of past governments (S. Smyth, pers. comm. 2010).

Throughout the 1980s and early 1990s, federal officials made a number of attempts to negotiate sectoral transfers to the Yukon territorial government, often in parallel with similar negotiations with the Government of the Northwest Territories (GNWT). In each territory, some transfers were completed, such as forestry to the Northwest Territories in 1986 and the Canada-Yukon Oil and Gas Accord in 1993. However, sectoral negotiations that addressed the issue with both territories never resulted in agreements. The substantial differences between the two territories in political imperative and social and political objectives (Cameron and White, 1995) meant in all instances that an agreement could work for one, but not for both.

In 1995, Ron Irwin, then Minister of Indian Affairs and Northern Development, appointed retired lawyer Robert Wright to review the devolution file. The Wright Report, submitted in April 1995, concluded that for the Northwest Territories, devolution should be put on hold until after division and creation of the new Nunavut Territory (Wright, 1995). Regarding Yukon, Wright advocated the bundling of remaining resources (land, forestry, minerals, and water) so that an overall comprehensive package could be put before the Yukon government and a quick negotiation could occur to bring about closure on the transfer of remaining "province-like" responsibilities. Indeed, Wright's analysis of sectoral transfers in the 1980s and 1990s led him to believe that the federal government would end up spending a lot of money with few tangible results if it continued with a sectoral transfer strategy. Instead, he recommended a more comprehensive transfer mainly because he felt that Yukon was politically and constitutionally ready and that a package deal was more feasible and cost-effective (Wright, 1995).

Wright seems to have underestimated the complexity of the proposed transfer, but the significance of his recommendations should not be understated. In particular, Wright saw the importance of bringing to the table all those matters that are inextricably linked. It is difficult to address mineral jurisdiction, for instance, without linking this discussion to where those minerals exist under Yukon land. Most topics relating to land management in one way or another interact with the presence of water, usually in the form of lakes and rivers or streams that are vital to indigenous fish or 
anadromous species such as migratory salmon. On a practical level, "bundling" successfully brought together central functions, thus resulting in economies of scale.

Following the Wright Report in 1995, the federal government extended a "take it or leave it" offer to Yukon in January 1997, culminating in the signing of the Yukon Devolution Protocol Accord in September 1998. Guided by this process document, negotiations between governments continued, and consultations with Yukon First Nations took place. The latter were required by Section 23.3 of the Umbrella Final Agreement, which stipulated that the position of the Yukon government in devolution negotiations may be developed with the input of the Council of Yukon Indians (now the Council of Yukon First Nations, CYFN). Once the UFA gave First Nations assurance that further devolution would not impede the resolution of outstanding land-claim negotiations, Yukon First Nations were generally supportive of devolution, which they regarded as the Yukon government's land claim (D. Leas, pers. comm. 2010; Alcantara, 2012).

The main benefit of devolution for Yukon First Nations was that it would be to their advantage to deal with local residents, who knew more about local needs and conditions, than with the distant federal government (D. Leas, pers. comm. 2010; P. McDonald, pers. comm. 2010). Although some Yukon First Nations (including the White River First Nation, the Ross River Dene Council, and the Liard First Nation) did not support the DTA, the fact that most Yukon First Nations (through CYFN) were prepared to engage in consultations with Yukon and Canada on devolution, can be contrasted to the situation in the Northwest Territories, where the relationship between the GNWT and Aboriginal groups is often strained (S. Smyth, pers. comm. 2010). From the perspective of Yukon government negotiators, the support of a majority of Yukon First Nations with completed land claims was a necessary condition to the successful pursuit of control and management of natural resources. In other words, Yukon government negotiators felt public government in Yukon must be built upon settled land claims since the management of natural resources and control of Yukon First Nations' traditional lands are intimately related (A. Robertson, G. Komaromi, B. Love, S. Abercrombie, P. Muir, pers. comm. 2010; Alcantara 2012).

Concurrently with its negotiations with the Yukon government, the Government of Canada engaged in a thorough review and substantive rewrite of the Yukon Act, the federal legislation that created the territory in 1898. This Act, which is effectively Yukon's "Constitution," was amended in 2001 to allow the Yukon government to legislate and thus to manage its land and resources. In addition to these jurisdictions, the amended Act captured principles of responsible government, which included removing the federal Minister's power to override territorial authority. There was also a strong desire on the part of the Yukon government to modernize the language of the Act to reflect the principles of the Epp Letter since the existing legislation made it appear as if the federally appointed Commissioner was still in charge of territorial affairs (P. Muir, pers. comm. 2010). Combined with the implementation of the Canada-Yukon Oil and Gas Accord (YOGA) and DTA, the new Yukon Act brought Yukon to "all but" provincial status.

Despite the support of the CYFN, the Yukon government still had to resolve several major issues with the federal government before a devolution transfer agreement could be reached. In particular, the Yukon government was apprehensive that the federal government would "claw back" any revenues generated by new resource development projects from the Territorial Financing Formula (TFF). The solution for the territorial government was to retain the first $\$ 3$ million generated by resource development projects, at which point the TFF would be reduced on a dollar-per-dollar basis. Although some Yukoners believe the $\$ 3$ million figure is too low, the premier at the time defended the provision, saying that financial aspects of such agreements are in a nearly constant state of negotiation and can be increased at a later date (P. McDonald, pers. comm. 2010). The debate may be moot since, to date, no resource development project in Yukon has hit the $\$ 3$ million cap (J. Cunning, pers. comm. 2010). However, with the current surge in mining exploration and mine development in Yukon, this figure is now a topic of serious discussion between the federal and Yukon governments and a major issue that all parties addressed in the 2011 Yukon general election.

Another major sticking point in negotiations was the financial liability of development projects approved by the federal government prior to the DTA. An oft-cited example is the Faro Mine, which will cost Canada well more than \$500-million to remediate and close the site. With the Yukon government unable, not to mention unwilling, to pay this amount, the settlement eventually reached by the federal and territorial governments was that liability for any projects approved prior to the DTA would be the responsibility of the federal government, while any projects approved by the Yukon government after devolution would be a territorial responsibility. This settlement was a calculated risk on the part of the Yukon government because of its much smaller tax base and increased costs related to support services such as firefighting ( $\mathrm{P}$. McDonald, pers. comm. 2010), especially if a development the territorial government approves requires extensive remediation (A. Robertson, G. Komaromi, B. Love, S. Abercrombie, P. Muir, pers. comm. 2010). Nevertheless, this settlement appears to have worked out to the advantage of the Yukon government since federal funds for the remediation of sites like the Faro Mine amount to a blank cheque rather than a lump sum (A. Robertson, G. Komaromi, B. Love, S. Abercrombie, P. Muir, pers. comm. 2010).

Despite a range of challenges faced in the negotiation of the transfer of associated federal bureaucrats to Yukon, most federal civil servants seemed to look forward to the transfer of the NAP. On one hand, they would have better access to decision makers and greater ministerial accountability (J. O'Farrell, pers. comm. 2010). Prior to that point, a federal employee could "work in the territory for ten years 
and never see their Minister" (S. Smyth, pers. comm. 2010). On the other hand, the relationship between DIAND's Regional Office in Whitehorse and headquarters in Ottawa had become strained. While it was easy for the Minister and other officials in Ottawa to duck and hide from inquiries and complaints, Yukon civil servants had nowhere to hide from applicants who had no qualms about coming right to their offices (B. McIntyre, pers. comm. 2010). For instance, after the federal government reneged on a Timber Harvest Agreement in Watson Lake, leading to successful litigation against DIAND, logging trucks circled government buildings in Whitehorse, impeding government officials' access to their offices (J. Cunning, pers. comm. 2010). Regional bureaucrats also resented being "chewed out" by the Minister's Office about phone calls Yukoners would regularly place to Ottawa to express their displeasure with the regulatory process, especially when Yukon had powerful MPs in Ottawa like Deputy Prime Minister Erik Neilson. Also, DIAND field officials in Yukon requesting increased funding for areas such as fire suppression would be frustrated by central departments such as Finance and the Treasury Board, which seemed to not understand why the Canadian government should be paying for programs that were not normally federal responsibilities (A. Robertson, G. Komaromi, B. Love, S. Abercrombie, P. Muir, pers. comm. 2010).

From a legal perspective, the DTA was a complicated agreement. While there is a common perception that the transition from federal to territorial control of the NAP was "seamless," a lot of legal work was done behind the scenes to integrate existing federal legislation into the new legal regime taking effect after 2003 (P. Muir, pers. comm. 2010). The complexity of the DTA required extensive consultations with numerous federal agencies, including the Privy Council Office, the Department of Justice, the Privacy Commissioner, the National Archives, the Language Commissioner, the Treasury Board, and the Department of Finance.

The DTA was a "blueprint" for the transfer of responsibilities from the federal to the territorial government, which meant that the territorial government still had to pass "mirror legislation" to cover areas of responsibility formerly administered by the federal government (J. O'Farrell, pers. comm. 2010). The problem is that the mirror legislation that came into effect after the passage of the DTA was antiquated, much like the Yukon Act discussed earlier. The Quartz Mining Act (QMA), for example, had not been amended since 1924. The antiquity of the legislation was of considerable concern to many in the mining industry as well as to other territorial groups such as environmental interests. In addition the mining industry was concerned that, following transfer, the Yukon government would allow other parties to be involved in the claim renewal process. This concern was assuaged once it was impressed upon the mining community that the renewal process would essentially remain unchanged after the transfer of the NAP to the Yukon government (P. Muir, pers. comm. 2010). Despite these challenges, including similar problems relating to water management, Yukon government negotiators decided it was best to first gain legislative control through mirror territorial legislation "with all its warts" since devolution could not occur without it (P. Muir, pers. comm. 2010). With the legislative jurisdiction in the hands of the Government of Yukon, it would be possible to address those "warts" over time through amendments in the Yukon Legislature.

Having overcome these challenges, the Government of Canada and the Yukon government reached the Yukon Northern Affairs Program Devolution Transfer Agreement on 29 October 2001. This agreement came into effect in 2003, 10 years after the signing of the Umbrella Final Agreement between the Council of Yukon Indians, the Government of Canada, and the Yukon government in 1993. Here we see the federal government pursuing a program of legislative and administrative decentralization with two different but interrelated groups of stakeholders in the same political jurisdiction at roughly the same time. According to some interviewees, the position of the federal government demonstrates a "genuine commitment" to political and economic development in Yukon (A. Robertson, G. Komaromi, B. Love, S. Abercrombie, P. Muir, pers. comm. 2010). Moreover, the federal government wanted to "reduce the bloated DIAND bureaucracy and to get out of the natural resources game" (A. Robertson, G. Komaromi, B. Love, S. Abercrombie, P. Muir, pers. comm. 2010). The federal government had essentially become the provincial government of Yukon but was ill-suited to running "provincial" programs and had become fatigued by the responsibility (P. McDonald, pers. comm. 2010). For instance, the federal government was in a constant state of irritation regarding opposition to its one-sided policy decisions, particularly as they related to land-use decisions in the forestry and mining sectors (P. McDonald, pers. comm. 2010).

Meanwhile, the Yukon government was eager to "get in" to service delivery and especially resource management (J. O'Farrell, pers. comm. 2010). For Yukon's political leaders, continued federal control over resources and the federal government's "faceless and unresponsive" approval process were untenable (P. McDonald, pers. comm. 2010). From the perspective of most members of the CYFN, "the more power the Yukon government gets, the more power the CYFN gets" (D. Leas, pers. comm. 2010). For the CYFN, local accountability meant greater capacity for Yukon First Nations to influence the use and management of the nearly $90 \%$ of their traditional territory not covered by final agreements (D. Leas, pers. comm. 2010).

In 2008, five years after the implementation of the DTA, the Minister of Indian Affairs and Northern Development commissioned Neil McCrank, an Alberta lawyer and former senior provincial bureaucrat, to write a report entitled "Road to Improvement: The Review of the Regulatory Systems Across the North." A common theme in discussions and workshops held by Mr. McCrank is that devolution has provided an additional layer of accountability by clarifying to industry stakeholders who is responsible for 
the regulatory process in Yukon (McCrank, 2008). He also noted that the UFA has made the Yukon resource management environment less complex than those in Nunavut and especially the Northwest Territories.

It is important to note, however, that McCrank openly admitted to focusing on the Northwest Territories and conducting only a "cursory" review of Yukon's regulatory and resource management regime. McCrank (2008:96) stated: "I did visit Yukon and Nunavut, but did not spend an extensive amount of time there, partly because what I observed over the short time I was there and what I've heard is that the system seems to be working reasonably well." As mentioned earlier, findings such as those presented in McCrank's report have gone largely untested. No one, it appears, has tried to measure the effectiveness and responsiveness of the transfer of the NAP to the Yukon government and the inclusion of the First Nations in resource management.

\section{ASSESSING DEVOLUTION: EFFICIENCY AND ACCOUNTABILITY}

In this section, we focus specifically on the permitting processes for land use and mining before and after the Devolution Transfer Agreement. Unfortunately, a statistical analysis of the number of land-use and mining permit applications processed in the decade before and after the DTA and the average amount of time taken to adjudicate such applications is not possible. Government officials informed us that the data necessary for such an analysis were either lost or never recorded, and our search of government records in Whitehorse and Ottawa confirms this fact. Consequently, the following section relies mostly on interviews with territorial, Aboriginal, and industry officials regarding the effect of devolution on the land-use and mining permit processes in Yukon. Despite this limitation, study participants were able to shed some light on the system of natural resource management that existed prior and subsequent to the YOGA in 1998 and the DTA in 2003, and the outcome of these legislative and administrative changes. Overall, all 16 of our interviewees reported that devolution has generally had a positive effect on the process and outcomes relating to land-use and mineral permits in the territory.

While the YOGA was certainly a historical political achievement for the Yukon government, the bulk of the analysis that follows will focus on the impact of the DTA on Yukon's land-use permitting process, given the weight of current pressures on land use and particularly land use associated with mineral exploration and development. It is also worth considering that the Yukon government's inclusion of First Nations in oil and gas negotiations forged a positive working relationship between the two groups and made it easier for that government to secure the support of the CYFN while negotiating the transfer of the Northern Affairs Program (D. Leas, pers. comm. 2010; A. Robertson, G. Komaromi, B. Love, S. Abercrombie, P. Muir, pers. comm. 2010). For example, the Yukon government and CYFN negotiated a Memorandum of Agreement that gave the latter group veto power over oil and gas projects on their settlement lands and ensured that no oil and gas developments would be permitted on First Nations traditional lands not covered by a land-claim settlement (D. Leas, pers. comm. 2010).

Focusing on the land-use permitting process in the Yukon, it is important to distinguish between land-use permits and land dispositions. Land-use permits are short-term access agreements granted for activities such as winter access, mining camps, and construction. Land dispositions, of which there are three types, represent long-term landuse arrangements. The first type of land disposition is the license of occupation, which allows applicants to occupy the land but does not grant them any rights to that land. The second is the lease, which gives applicants more permanent and exclusive use of the surface lands. Finally, title gives applicants ownership of the land and full surface rights. Subsurface use and rights must be obtained through a Mining Land Use Permit, granted pursuant to the Mining Land Use Regulations Act and associated regulations. Placer mining is covered by separate legislation and is not part of this study.

Prior to the enactment of the DTA in 2003, the majority of land in the territory was controlled by the federal Territorial Lands Act. The Yukon government controlled only small portions of land in and around incorporated communities such as Whitehorse and Dawson City. Before 2003, applications for general and mining land use were assessed under the Canadian Environmental Assessment Act (CEAA), with DIAND responsible for doing environmental assessments triggered by particular land-use and resource development applications (B. McIntyre, pers. comm. 2010). The result of the "self-assessments" conducted by the federal government was that the land-use permitting process was highly integrated, and timelines for approval were condensed (B. McIntyre, pers. comm. 2010).

During that time, mining land-use regulations required a decision to be made within 42 days of an application although department policy was for applications to be sent out for comments and consultation and returned within 21 days (J. Colbert, B. Sproule, M. White, pers. comm. 2010). CEAA did not have any timelines. In practice, any interested party could provide feedback on a land-use permit application and groups that were consulted generally included Environment Canada, the Water Board, the Yukon government, and affected First Nations (J. Colbert, B. Sproule, M. White, pers. comm. 2010). Yukon First Nations, however, alleged public consultation under the "old" system was not extensive or responsive enough to local Aboriginal and territorial concerns, especially since the Act failed to specify how the required consultation was to take place (B. McIntyre, pers. comm. 2010; J. Colbert, B. Sproule, M. White, pers. comm. 2010).

Yukoners were also constantly aggrieved by the Federal-Territorial Land Application Committee (FTLAC), 
the body responsible for adjudicating land dispositions. Although the experts and federal government officials that composed FTLAC generally rendered decisions within three to six months, it was not uncommon for several years to pass before decisions were made. Applications for cottage lands, for instance, were particularly notorious for languishing before FTLAC. Even the territorial government had to endure protracted land disposition applications that required federal ministerial review and a federal Order-inCouncil (B. McIntyre, pers. comm. 2010).

Most of the reasons why land dispositions took so long to adjudicate relate to the fact that the decision-making power was located in Ottawa rather than Whitehorse. One factor was the remoteness of federal officials in Ottawa. Another factor was the number of required federal interdepartmental consultations. Since decisions required high-level involvement from the federal government's Department of Justice, Treasury Board, Department of Finance, and Privy Council Office, it took "years and years" for things to get done compared to post-devolution (B. McIntyre, pers. comm. 2010). Other reasons likely included the uncertainty related to the completion of outstanding land claims (D. Leas, pers. comm. 2010; A. Robertson, G. Komaromi, B. Love, S. Abercrombie, P. Muir, pers. comm. 2010); insufficient clarity from the Courts on the extent to which consultation was required; lack of CEAA timelines; and competing land-use issues. The very first day the administration of land use and mineral development was devolved to the territorial government, there was a "mad rush" of people to the Yukon government offices, and it took territorial civil servants three years to clear the backlog of applications that had accumulated under DIAND's watch (B. McIntyre, pers. comm. 2010).

For the first two years after the passage of the DTA in 2003, land-use permits and land disposition applications were reviewed under the territorial Yukon Environmental Assessment Act (YEAA), the mirror legislation to the federal CEAA. Former federal employees treated the old and new Acts in much the same way, with decisions generally being made within four months (J. Colbert, B. Sproule, M. White, pers. comm. 2010). The timeframe for applications to be adjudicated was largely similar under CEAA and YEAA (B. McIntyre, pers. comm. 2010).

For all intents and purposes, the assessment environments under CEAA and YEAA were identical. It was not until the enactment of the Yukon Environmental and SocioEconomic Assessment Act (YESAA) in 2005 that Yukon's land use and resource development application process began to undergo significant changes. YESAA is the federal legislation that replaced YEAA and was enacted in fulfillment of obligations under chapter 12 of the Umbrella Final Agreement, signed by the Council of Yukon First Nations and the federal and territorial governments. The significance of YESAA is three-fold. First, the Act eliminated the environmental self-assessment model found in CEAA and YEAA by taking away the environmental assessment function from the core regulator, DIAND under CEAA and
Yukon government under the brief life of YEAA. Second, the Act added socio-economic assessment in its own right, independent of the environmental impacts, to the overall assessment process. In addition, YESAA ensures that a proponent fully considers potential environmental and socio-economic impacts and required mitigation before the regulators (federal, territorial or First Nation) are legally able to approve and license a development.

The new functions introduced by YESAA became the responsibility of the Yukon Environmental and SocioEconomic Assessment Board (YESAB). YESAB is a single, independent environmental and socio-economic assessment body created under the authority of the federal Act. YESAB comprises representatives from Yukon First Nations, the Government of Canada, and the Yukon government and is responsible for applications from across the entire territory, whether these relate to federal, territorial, First Nation, or municipal lands. All new projects require a YESAA assessment if activities are triggered by particular resource development projects as described in associated regulations. Thus, the introduction of YESAA in 2005 ushered in a "new" two-step application process for land-use and resource development permits, with YESAB responsible for conducting the environmental and socio-economic assessments. Ultimate authority to "accept, reject or vary" the assessment recommendations rests with the federal, territorial, and First Nations governments, as does responsibility for regulatory decision making and licensing following the assessment.

The context under which YESAB operates can be contrasted to that of the Northwest Territories, where separate land claims have led to several different environmental assessment boards with real decision-making authority and different assessment regimes (K. McKinnon, pers. comm. 2010). Conversely, YESAB is neither a regulatory nor quasi-judicial body but makes recommendations to what are referred to in the YESAA as "decision bodies." Depending on the nature of the "trigger" that requires the assessment to be conducted, recommendations from YESAB are sent to one or more of the following decision bodies: First Nations, if the project in question is on First Nation settlement lands under a modern treaty; the Yukon government acting as one integrated body; or any federal government department or agency whose jurisdiction is affected by recommendations from YESAB, such as the Department of Fisheries and Oceans if there are potential implications for anadromous fish or any fish habitat.

In the case of mineral exploration and development, the Yukon government is the formal decision body, and its Department of Energy, Mines and Resources (EMR) takes the lead role. Such decision bodies issue what are known as "decision documents," which can accept, reject, or vary a YESAB recommendation. Applications may be rejected because of the impact proposed developments might have on the environment, especially wildlife and habitat. Denied applications cannot be appealed, but they can be resubmitted with necessary changes. In most cases, the Yukon 
government allows projects to proceed with conditions that reflect the YESAB recommendations in the decision document. The government may also include in a decision document any other matter that the EMR (as the technical lead) believes requires care and attention by the proponent, such as matters captured in regulation that are not part of the environmental and socio-economic assessment (B. McIntyre, pers. comm. 2010).

Since its inception in 2005, YESAB has conducted 1076 environmental assessments and frequently completes assessments ahead of the maximum timelines established under the YESAA legislation (K. McKinnon, pers. comm. 2010). Between 1 January 2005 and 4 November 2010, the average time between the submission of proposals and the sending of recommendations was 55.44 days. During that time, YESAB conducted 238 environmental assessments for the placer mining sector, which accounted for the highest percentage (23\%) of all land use applicants. YESAB also completed 212 environmental assessments for residential, commercial, and industrial land development (20\%) and 137 environmental assessments for quartz mining proponents (13\%), the next highest sectors. Residential, commercial, and industrial development was the fastest of the three sectors to be approved, at an average of 54.31 days, slightly ahead of placer mining (57.2 days) and quartz mining (61.2 days). Although comparative data for permits adjudicated before 2005 are unavailable, the president of YESAB stated that the number of environmental assessments completed after the introduction of YESAB is significantly higher than before 2005 (K. McKinnon, pers. comm. 2010).

Since 2005, Yukon has been described as one of the world's best mining jurisdictions because of its very stable political climate, good transportation and energy infrastructure, and demonstrably pro-mining government. These characterizations are supported by the Fraser Institute's annual mining survey (Cervantes and McMahon, 2011), which regularly places post-devolution Yukon near the top of its Policy Potential Index for best mining jurisdictions within Canada and around the world. Although these results can probably be attributed at least in part to world economic factors, the Yukon mining industry expanded at an annual average rate of $10.5 \%$ between 2003 and 2008 . This figure far exceeds the $3.1 \%$ growth of all other industries, with mineral exploration spending in 2010 forecast to match the 2007 record of $\$ 140$-million (see Dashkov, 2010). Also, it is worth noting that Manitoba and Yukon were the only Canadian jurisdictions to experience positive GDP growth in 2010 because of mining activity (G. Komaromi, pers. comm. 2010).

From the perspective of the mining industry, the Umbrella Final Agreement has created greater "certainty" regarding land claims, since 11 of 14 Yukon First Nations have endorsed the agreement, while YESAA's strict timelines have created greater "certainty and efficiency" (M. Wark, pers. comm. 2010). In addition, the Yukon government has borne many of the costs associated with mining activities, such as housing and healthcare, using funds received from its tax base and federal transfers (P. McDonald, pers. comm. 2010). The mapping and surveying done by the Yukon government has also fostered the mining industry in the territory (M. Wark, pers. comm. 2010).

\section{CONCLUSION}

In 2003, a number of prominent Yukoners spoke with great optimism about devolution. Scott Casselman, then vice-president of the Yukon Chambers of Mines, embraced the agreement, saying that it would allow those who were directly involved and knowledgeable about mining in the territory to have a greater say and thus produce more efficient and responsive mining outcomes in the territory. Leonard Pierson of the Yukon Forest Industry Association agreed, observing that "we've had a long and difficult journey with the previous DIAND forestry program. We're certainly looking forward to a more accommodating and directly involved group of government people there [postdevolution]." Karen Baltgailis of the Yukon Conservation Society echoed these hopes, stating that "now we'll just be able to make those decisions in the Yukon and we won't have to wait for Ottawa to let that process happen" (CBC, 2003). The data presented in this paper confirm these optimistic sentiments, indicating that devolution has made the land-use and mining permit processes more responsive and effective. The findings are also consistent with the generally positive perceptions of devolution, as reported in the latter half of the history section. In short, Yukon's experiences with devolution confirm some of the arguments made in the literature regarding devolution in Canada and abroad.

The Auditor General of Canada stated in 2003 that Yukon devolution was "a historic event that marked a significant step in nation building" (Canada, 2003:17). For those most intimately involved in the negotiations, the YOGA, DTA, and amended Yukon Act were a "natural evolution" of the Epp letter in 1979 and the Northern Economic Framework of 1987 (A. Robertson, G. Komaromi, B. Love, S. Abercrombie, P. Muir, pers. comm. 2010). From the perspective of the CYFN, the Yukon government secured a fair deal that coincided with the winding down of the landclaim process (D. Leas, pers. comm. 2010). Despite some lingering dissatisfaction, Yukon's political parties have limited themselves to debate over specific aspects of the agreement rather than questioning the legitimacy of the entire agreement (A. Robertson, G. Komaromi, B. Love, S. Abercrombie, P. Muir, pers. comm. 2010). In many ways, the confluence of the political maturation of the Government of Yukon, the insistence and growing political sophistication of Yukon First Nations, and shifting attitudes and priorities of the federal government and its departments, especially DIAND, have made it possible for Yukon to shed its colonial past and solidify its position within the Canadian federation. 


\section{ACKNOWLEDGEMENTS}

This research was funded by a SSHRC Strategic Research Grant - Northern Communities: Towards Social and Economic Prosperity, grant \#866-2008-0003. The authors would like to thank the reviewers of this journal for their suggestions and the interviewees who generously shared their time and information with us.

\section{REFERENCES}

Abele, F., Courchene, T.J., Seidle, F.L., and St-Hilaire, F., eds. 2009. Northern exposure: Peoples, powers and prospects in Canada's North. The Art of the State, Vol. 4. Montreal: Institute for Research on Public Policy.

Alcantara, C. 2005. Certificates of possession and First Nations housing: A case study of the Six Nations housing program. Canadian Journal of Law and Society 20(2):183-205.

- 2012. Preferences, perceptions, and veto players: Explaining devolution negotiation outcomes in the Canadian territorial North. Polar Record, doi:10.1017/ S0032247412000125.

Alcantara, C., and Whitfield, G. 2010. Aboriginal self-government through constitutional design: A survey of fourteen Aboriginal constitutions in Canada. Journal of Canadian Studies 44(2):122-145.

Beaubier, P.H., and Beaubier, T.K. 2002. A review of the devolution experience in Yukon: Lessons learned. Unpubl. report commissioned by the Government of the Northwest Territories, Yellowknife. Available from Yukon Archives Library, Box 2703, Whitehorse, Yukon Y1A 2 C6.

Bradbury, J., and Mitchell, J. 2005. Devolution: Between governance and territorial politics. Parliamentary Affairs 58(2):287-302.

Bukowski, J. 1997. Decentralization in Spain: A re-evaluation of causal factors. South European Society and Politics 2(3):80-102.

Cameron, K., and Campbell, A. 2009. The devolution of natural resources and Nunavut's constitutional status. Journal of Canadian Studies 43(2):198-219.

Cameron, K., and Gomme, G. 1991. The Yukon's constitutional foundations, Volume 2: A compendium of documents relating to the constitutional development of the Yukon Territory. Whitehorse: Northern Directories Ltd.

Cameron, K., and White, G. 1995. Northern governments in transition: Political and constitutional development in the Yukon, Nunavut and the Western Northwest Territories. Montreal: Institute for Research on Public Policy.

Canada. 2003. 2003 Indian and Northern Affairs CanadaTransferring federal responsibilities to the North. Chapter 8 in Report of the Auditor General to the House of Commons. http://www.oag-bvg.gc.ca/internet/docs/20031108ce.pdf.

CBC (Canadian Broadcasting Corporation). 2003. It's official: Yukon devolution in effect. CBC Online News, April 1.

Cervantes, M., and McMahon, F. 2011. Survey of mining companies: 2010/2011. Vancouver: The Fraser Institute.
Clancy, P. 1990. Politics by remote control: Historical perspectives on devolution in Canada's North. In: Dacks, G., ed. Devolution and constitutional development in the Canadian North. Ottawa: Carleton University Press: 13-42.

Coates, K., Lackenbauer, P.W., Morrison, W.R., and Poelzer, G. 2008. Arctic front: Defending Canada in the far North. Markham: Thomas Allen Publishers.

Dacks, G., ed. 1990. Devolution and constitutional development in the Canadian North. Ottawa: Carleton University Press.

Dashkov, A. 2010. Yukon fever: Today's hottest area play. http:// www.kitco.com/ind/Dashkov/nov172010.html.

de Vries, M.S. 2000. The rise and fall of decentralization: A comparative analysis of arguments and practices in European countries. European Journal of Political Research 38:193-224.

Escobar-Lemmon, M. 2003. Political support for decentralization: An analysis of the Colombian and Venezuelan legislatures. American Journal of Political Science 47(4):683-697.

Fentie, D. 2003. Devolution will lead to positive changes for Yukon. The Hill Times, February 10.

Føllesdal, A. 1998. Survey article: Subsidiarity. The Journal of Political Philosophy 6(2):190-218.

Hayek, F.A. 1945. The use of knowledge in society. American Economic Review 35(4):519-530.

Henderson, A. 2007. Nunavut: Rethinking political culture. Vancouver: UBC Press.

Hoefer, T. 2009. Diamond mining in the Northwest Territories: An industry perspective on making the most of northern resource development. In: Abele, F., Courchene, T.J., Seidle, F.L., and St-Hilaire, F., eds. Northern exposure: Peoples, powers and prospects in Canada's North. The Art of the State, Vol. 4. Montreal: Institute for Research on Public Policy. 395-414.

Hueglin, T.O. 2007. The principle of subsidiarity: Traditionpractice - relevance. In: Peach, I., ed. Constructing tomorrow's federalism: New perspectives on Canadian governance. Winnipeg: University of Manitoba Press. 201-218.

Martin, D., Bélanger, D., Gosselin, P., Brazeau, J., Furgal, C., and Déry, S. 2007. Drinking water and potential threats to human health in Nunavik: Adaptation strategies under climate change conditions. Arctic 60(2):195-202.

McArthur, D. 2009. The changing architecture of governance in Yukon and the Northwest Territories. In: Abele, F., Courchene, T.J., Seidle, F.L., and St-Hilaire, F., eds. Northern exposure: Peoples, powers and prospects in Canada's North. The Art of the State, Vol. 4. Montreal: Institute for Research on Public Policy. 187-232.

McCrank, N. 2008. Road to improvement: The review of the regulatory systems across the North. Ottawa: Indian and Northern Affairs Canada.

Michael, J.M. 1987. From Sissons to Meyer: The administrative development of the Yukon Government, 1948-1979. Report prepared for Yukon Archives, Whitehorse. http:// yukondigitallibrary.ca/Publications/SissonsMeyer/From $\% 20$ Sissons $\% 20$ to $\% 20$ Meyer.pdf.

Natcher, D.C., and Davis, S. 2007. Rethinking devolution: Challenges for Aboriginal resource management in the Yukon Territory. Society \& Natural Resources 20(3):271 - 279. 
Rodríguez-Pose, A., and Gill, N. 2002. The global trend towards devolution and its implications. London: London School of Economics, Dept. of Geography and Environment.

Rondinelli, D. 1980. Government decentralization in comparative perspective: Theory and practice in developing countries. International Review of Administrative Sciences 47(2):133-145.

Smoke, P. 2003. Decentralisation in Africa: Goals, dimensions, myths and challenges. Public Administration and Development 23:7-16.

White, G. 2008. "Not the Almighty": Evaluating Aboriginal influence in northern land-claim boards. Arctic 61(Suppl. 1): $71-85$.
2009. Nunavut and the Inuvialuit Settlement Region: Differing models of northern governance. In: Abele, F., Courchene, T.J., Seidle, F.L., and St-Hilaire, F., eds. Northern exposure: Peoples, powers and prospects in Canada's North. The Art of the State, Vol. 4. Montreal: Institute for Research on Public Policy. 283-316.

Whitford, A.B. 2002. Decentralization and political control of the bureaucracy. Journal of Theoretical Politics 14(2):167-193.

Wright, R. 1995. Report to the Honourable Ronald Irwin re the devolution by DIAND of provincial-like powers to the Yukon and Northwest Territories. Available from Yukon Archives Library, Box 2703, Whitehorse, Yukon Y1A 2C6.

Yukon Government. 2001. Yukon Northern Affairs Program Devolution Transfer Agreement. Ottawa: Minister of Indian Affairs and Northern Development. http://www.aadnc-aandc. gc.ca/eng/1297283624739. 